\title{
COPING UP WITH COVID-19 IN INDIA: A NEW WAY OF SURVIVING INDIAN HOSPITALITY INDUSTRY
}

\author{
Dr Ruchita Verma \\ NMIMS School of Hospitality Management,NMIMS University,Mumbai,India \\ Dr. Ketan Chande \\ Dean, Associate Professor, NMIMS School of Hospitality Management,NMIMS \\ University,Mumbai,India \\ Bimal Kumar Ekka \\ Assistant Professor, NMIMS School of Hospitality Management,NMIMS \\ University,Mumbai,India
}

\begin{abstract}
India's hotel and hospitality industry occupancy decreased significantly in the first quarter of 2020, as the outbreak of COVID-19 affects different segments of the market. The outbreak of the novel coronavirus (COVID-19) has inflicted a blow on industries around the world, but maybe none as devastating as hospitality and travel. Depending on the length of the pandemic, companies across the industry adjusted growth forecasts for 2020, estimated profits to be conservatively 40-50 percent lower than expected before the outbreak. The effect on hospitality demand is greater than many other sectors, but even among hotels, air and cruise ships, and restaurants it is varied. Hotels and airlines operate at half capacity, with both business and leisure travellers cancelling scheduled trips and not arranging any for the near future. The present article aims to study some novel practices for the survival of hospitality industries once the lockdown is over.
\end{abstract}

Key words: Hotels, Pandemic, Crisis, Business.

Cite this Article: Ruchita Verma, Ketan Chande and Bimal Kumar Ekka, Coping up with Covid-19 in India: A New Way of Surviving Indian Hospitality Industry, International Journal of Management, 11(12), 2020, pp. 1549-1558.

$\mathrm{http}: / /$ iaeme.com/Home/issue/IJM?Volume $=11 \&$ Issue $=12$ 


\section{INTRODUCTION}

The outbreak of COVID-19 is not a danger, it is a hotel industry tragedy. That is to say, it's a disastrous occurrence that comes from outside the hotel industry that has little influence over the hotel industry.

In the global tourism and hospitality industry, the spread of COVID-19 and large-scale travel restrictions continue to wreak havoc. According to an open letter from Gloria Guevara, President and CEO of the World Travel \& Tourism Board, because of the pandemic, '50 million jobs worldwide are at risk.' The letter further suggests that because of the COVID-19 global health crisis, the travel and tourism industry is already facing collapse" and is in a fight for survival." Hotels, along with a downturn in economic development, are particularly vulnerable to decreased tourism and travel. The COVID-19 pandemic has caused serious blows on hoteliers around the world as events around the world continue to be cancelled or postponed and hotel occupancy rates are dropping.

The effect of COVID-19 on the hotel industry in India has been massive. The full impact is unknown, because the final outbreak scale has yet to be determined. Travel constraints and social distance policies have had a dramatic impact on the industry, however. In India, hotel occupancy fell and revenue per room available decreased as well. According to The World Travel and Tourism Council (WTTC) reports, there would be more than 50 million jobs could be at global risk in the travel and tourism sector. In view of the uncertainty, hotel operators have begun to take action, with either ongoing or expected furloughs, hotel suspensions and personnel cuts. At the same time, they introduce flexible cancelation / rebooking policies, modify the loyalty program criteria and introduce other steps that will help them adapt more to consumer needs. The industry however has a huge task ahead of it. Government support is needed, and that will help. Present forecasts expect a significant economic recession in the first half of the year, followed by a rebound in the latter half. Even so, there is concern that prolonged economic instability may be present which would prevent a rapid rebound. So if hotels acclimate to this economic fact, they will have to think both in the short and the long term regarding key issues.

\section{IMPACT OF COVID 19 ON HOSPITALITY SECTORS}

After a record year in 2019, the Indian hotel sector worked smoothly until January 2020, with 2020 predicted to be much bigger." At the end of February 2020, the nation began to feel the ripple effects of the global COVID-19 instability, which worsened at the beginning of March. Hotel occupancy in key cities has declined gradually and has decreased by an incredible 45 percentage points compared to the previous year according to our estimates. Never in such a short amount of time has the industry seen such a steep decline.

The study predicts that the worst impacted will be the second quarter of the year. Hotels will not be able to push rates and may also seek to attract deep discount businesses.

In 2020, total occupancy in the branded hotel segment is projected to decrease by 16.7-20.5 percentage points over 2019, while ADRs are projected to decrease by $7 \%$ to $8 \%$ over the year. As a consequence, from 31 per cent to 36.2 per cent, RevPAR will see a substantial decrease. 


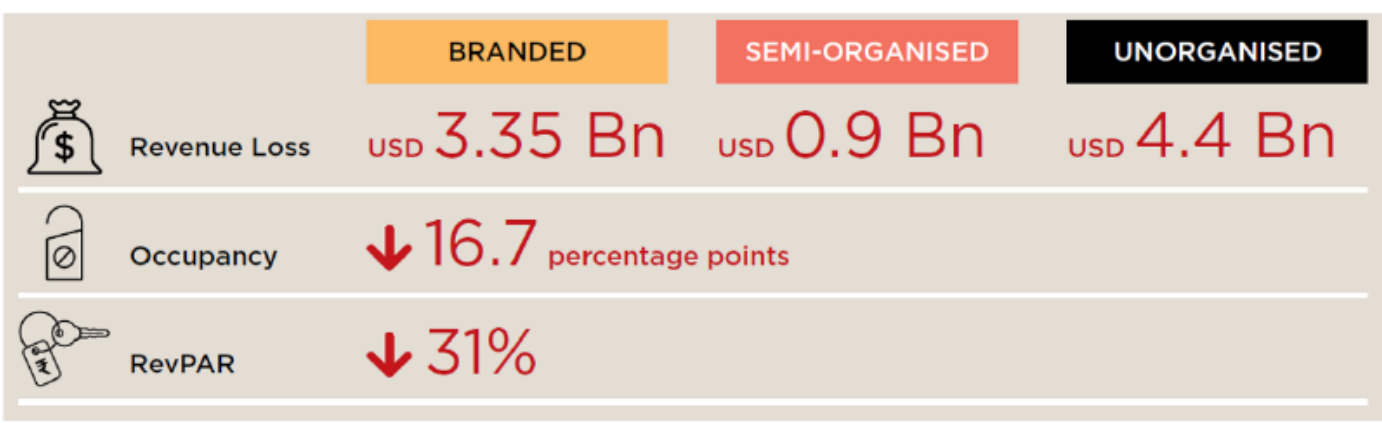

Figure 1

Source: HVS Research; *Analysis based on data available as of 23rd March 2020

The Indian hotel industry's total revenues are therefore projected to fall anywhere from US\$ 8.85 billion to US\$ 10 billion, reflecting a drop of $39 \%$ to $45 \%$ over the previous year. In addition to direct business losses, hotel owners will also experience losses as a result of fixed operating expenses, repayment of debt, interest payments and any other enforcement that would be required to occur within the sector.

\section{KEY CONCERNS FOR HOTEL INDUSTRY AFTER COVID 19}

Once the hotel businesses respond to this pandemic and recover, consideration will be given to how to expand. There will be strategic alternatives not previously available and companies should begin to talk about:

- A Does there need to be considered permanent changes in the hotel operations?

- Is hygiene and sanitation are the most important and how are you making plans to maintain all hygiene standards?

- How does post-pandemic hospitality look like?

- What patterns of demand will change or might change?

- Where does the changing world build opportunities?

- How would you prepare yourself to seize the opportunities?

- How can your operations build resilience to protect you against future similar shocks and disruptions?

\section{SURVIVAL STARATEGIES FOR COPING UP COVID 19: A NEW BUSINESS MODEL}

When we talk about the survival of hotel industries as they have severely impacted due to Covid 19 , the two questions comes in a way:

\subsection{What is the need for hotels after Covid 19 to concentrate on business?}

The most important thing in the present situation is to "survive" and you have reached your milestone of achievement if you are able to do so.

Adding to this, it is also not a secret reality that it would be much more difficult for you to draw visitors to your property again once this gets better.

And so, preparing for the future of your company is very important to you.

Hence, you should be well positioned to get your company back on track by the time this pandemic recedes. 


\subsection{How to lift your hotel after the outbreak of COVID19?}

Now it's the perfect time for you to schedule, strategize and prepare for a post-COVID-19 period while you are in quarantine house.

We know, reaching out to new guests is more difficult than retaining current guests. So you will certainly be missed when COVID-19 becomes under control if you stay quiet now rather than keeping up to your guests.

Here are some strategies given by the experts to get the business back in the flow:

\subsubsection{Emphasis on rising customer experience}

This crisis has led to a number of factors fogging up the hospitality sector's prospects. The culture of sharing, as well as food, container and human contacts has been stopped during the outbreak of measures to avoid cross-contamination. In reality, since the outbreak was limited, the hotel industry would have to prepare to increase dramatically the demand for tourism.It is crucial to ensure that hotels manage their resources and adapt to this sudden rise while providing service quality.

As customer preferences shift after the outbreak is complex, hotels need to review their current service offerings to resolve changes in client behavior. Hotel restaurants can start offering their own spoons when they deliver a common dish, encourage contactless delivery to restaurants and design menus in single parts rather than sharing dimensions. Therefore hotels must prepare their employees for planning, define bottlenecks for services, allocate resources and sustain pre-sales cash flow in order to meet the sudden increase in demand without compromising quality of service.

\subsubsection{Emphasis on the switch in customer perceptions}

The reason for this crisis is an insufficient choice of raw food, which would, in turn, have an important effect on the customer's diet and values. The health of food products after the outbreak is expected to be paid more attention by customers. If taste is taken into account, however, consumers may be more reliant on the safety source of the ingredients, their purity, their good handling and their nutrient wealth.

In response to this shift in the perception of the market, hotels must make suitable changes, such as a return to conventional hotel standards, comply strictly with HACCP and promote the importance of hygiene in their organization. When choosing raw materials with high hygiene standards hotels will enhance their productivity and create a "clean image of hotel F\&B offers compared to standalone restaurants. This helps raise brand visibility and creates more $\mathrm{F} \& \mathrm{~B}$ purchases from the local population as well as hotel guests.

\subsubsection{Emphasis towards consumption patterns}

To help tackle the epidemic effectively, most consumers prevented themselves from shopping for food, instead concentrating on delivery services, thus promoting the growth of online sales and promotion. In addition, as customer social needs are not desirable, many business owners and individuals have used social media channels to publicize products or share experiences through live radio broadcasting and on-line interaction. Their social needs have also shifted.

Hotels must use the existing online channels to improve customer engagement in order to deal with changing consumption habits. Several hotels have already expanded their online catering services during the epidemic. After the outbreak of the outbreak, hotels can retain this channel and give the local community daily packaging for To-Go and Bento box distribution, an alternative that addresses customer needs, generates extra income and enhances the "perfect picture" of hotels. Hotels can also use their many online platforms to understand and respond 
efficiently, from one-way communication to two-way collaborative communication, to these networks in an efficient way, and on time.

\subsubsection{Emphasis on quality asset management}

The disease had a huge effect on the hospitality industry as a whole and led to the complete closure of some hotels because of the lack of cash flow support. Some owners of hotels may decide to sell properties with these assets, while others may renovate or rebuild themselves to increase the competitiveness of these assets.

The reason hotels should use a sustainability model after the outbreak not only describes how rivals respond but most significantly, also offers a thorough overview of the features of customer requirements.In some cases, it is necessary for some independent hotels to improve the brand culture and quality standards to respond to customer demand. Hotel owners and operators must analyse the position of the brand in order to better understand the needs of the target audience.

Hoteliers would also involve optimization of asset strategies, renovation or reconstruction of large scale properties, and improvement in asset quality to meet growing consumer needs. In the case of poor performance of assets, the center of the asset portfolio needs to be handled adequately in a timely manner.

\subsubsection{Other Factors}

As we can see, economies are shrinking, people will lose their jobs, companies will shut down and there are endless implications. And business travellers would rather have one-to-one meetings online for a while.

Hotels like you will take different measures in these days to deal with this crisis. These look most promising and will allow your property to survive this crisis over the long term. Some may have been:

- Cost management implementation

- Embracing automation and technology

- Employee training priority

More useful survival advice for hotels during COVID19 are available in this article.

Using tactics for the low season

Oh, you should have focused on your high and bad seasons at the beginning of this year. But who knew it would be entirely a weak season this year. And we know that during such periods it is difficult to reach maximum hotel occupancy, but this will change soon as well. Therefore it would be clever to apply the low season tactics after this pandemic. Make sure you do this creatively.

\section{Apply to OTAs}

While you can concentrate on reducing your costs, it's the best time to list as many OTAs as you can. With more OTA links, you can produce full revenue and reach more visitors.

\section{Boost OTA rankings}

Today, steps must be taken to boost your OTA rankings. With a strong rating on OTAs, your guests will prefer your property over other properties (or your competitors). Of course, the better the OTAs you have the more reservations you get. If you want to lift your hotel business after COVID19, you cannot overlook that. 


\section{Focus on your image online}

More than ever before post COVID19, your reviews and ratings will be key. Are you safe and sanitary in your premises? You'd like to know about it to your guests. So, make sure you track closely how current guests and future guests project and interpret your brand. The most definite approach is to focus on your reputation for long-term benefits. So it's not late to do that, though you haven't begun it until now.

\section{Take part in OTA promotions}

Well in the days pre-COVID, before international travel in most countries was shut down, OTAs had numerous deals, promotions and reservations promoted. Take a look at updates from OTAs during resumes on travel - they can push new guidelines and procedures for promotions or reservations to get a good idea of what to do.

\section{Introduce acceptable prices, rebates and promotions}

To follow up your hotel business, it is important to adopt a systematic price strategy. So consider and reflect on the circumstances of your guests at the moment. Therefore, brace yourself with some powerful price packages and discount offers. It will certainly benefit you to obtain reservations at your hotel. We know it will cost you a lot, but it will keep your company on track over time.

\section{Establish appropriate cancellation policies}

A correct and stupid cancellation policy is required before your website and other channels are available. This will be an important factor in making reservations following this outbreak.

\section{Start marketing in social media}

The best way to get more reservations, increase brand value and connect and attract more guests is through social media. It's therefore important for you to be active in the social field and to post regularly on all your social media profiles, combo packages, and offers. But now is the best time to get started if you're not active in these platforms.

\section{Website and SEO efficiency optimisation}

You can start working on your hotel and SEO website while staying at home while at this lockdown. A website optimise the ranking and visibility of your hotels on Google, Yahoo and other search engines.

\section{Train employees}

Your staff is the final point of contact for your guests now and even after the COVID-19 era. It is therefore very important that you make them aware of them and train them to provide excellent guest experience. Do this through online training for all your employees. Also get them trained in that when you use hotel technology. This helps you remain committed to improving hotel operations and offering the best guest experience.

\section{Ensure the right cleanliness and sanitation}

During or after this outbreak, proper hygiene, sanitation and cleanliness will be your guest's primary priority. To do this, inform your staff of the measures to prevent them from taking on your hotel premises. In addition, thoroughly sanitise your hotel. Install the hand rub hand dispensers for disinfectant alcohol in your property's maximum areas. And while all of these things are being done, highlight them on your site, on social media and any possible link to your guests. 


\section{Connect to tour operators}

Travel agents are a source of additional income when OTAs, meta search engines and others do not work well. Connecting with them will not only help you display your presence but also make more reservations for your guests. We're sure that you've already been linked to several travel agents. However, if you haven't yet seen that as a strategy, it's time you ought to! I look forward to talking to new and international travel agencies as well (those are less impacted with COVID-19).

\section{Check the travel history of your guests}

Well as you know, this deadly virus has largely affected the world through international travel and group transmission. And we're sure you don't want the title of your hotel after this period. To ensure the safety of your guests, keeping track of your foreign guests and their travel history is your top priority. This would be the worry of your guests because of the fear of getting in touch with the virus. This is simply just an extra measure you can take.

\section{CONCLUSION}

The global panic of COVID-19 may have lasting travel repercussions. Successful measures are required to raise the morale of travellers and to help companies recover in time after this crisis. Resilience and sustainability of the hotel industry can be improved by resolving various consumption criteria and taking measures to turn adversity into chance. These initiatives are consistent with expected consumer demand patterns such as the wellbeing of travellers, contactless services and protection of the environment. Hotels are showing a variety of areas where technical expertise can be progressed in connection with this pandemic and competitive consumer demand. Reflecting on changing traveller preferences and industrial recovery programmes, academias will help facilitate meaningful improvements to business practises following this pandemic to the theory of hotel marketing and management.

Above all, we just don't know when this process will happen and how much more the hotel industry will be affected. However, in these critical times, it is time for us to do whatever we can to maintain our company. Start by concentrating on the above strategies and prepare your property for this hardest phase of your business.

Don't lose faith, last but not least. Time will change, things are coming back and the visitors are at your door soon. The time will change. We are together in this and soon we are going to combat this crisis. Just stay home. Stay home. Keep tight. Until that time, cultivate your hotel business after COVID19 and start preparing to grow

\section{REFERENCES}

[1] Jiang, Yangyang \& Wen, Jun. (2020). Effects of COVID-19 on hotel marketing and management: A perspective article. International Journal of Contemporary Hospitality Management. 10.1108/IJCHM-03-2020-0237.

[2] WHO. 2020a. "Q\&A on coronaviruses (COVID-19)", available at: https://www.who.int/newsroom/q-a-detail/q-a-coronaviruses.

[3] Li, J.J., Bonn, M.A. and Ye, B.H. 2019. "Hotel employee's artificial intelligence and robotics awareness and its impact on turnover intention: The moderating roles of perceived organizational support and competitive psychological climate", Tourism Management, Vol. 73, pp. 172-181. 
[4] Hoisington, A. 2020. "5 insights about how the COVID-19 pandemic will affect hotels", available at: https://www.hotelmanagement.net/own/roundup-5-insights-about-howcovid-19pandemic-will-affect-hotels

[5] Courtney, E.J. 2020. "COVID-19 will cause a significant decline in global RevPAR, cash flow, for rated lodging companies", available at: https://www.spglobal.com/ratings/en/research/articles/200311-covid-19-will-causeasignificant-decline-in-global-revpar-cash-flow-for-rated-lodging-companies1 1382396\#ID493 $\mathrm{Gu}, \mathrm{H}$. and Ryan, C. 2

[6] Ranasinghe, Ruwan \& Damunupola, Anupama \& Wijesundara, Shamila \& Karunarathne, Chandi \& Nawarathna, Dhananjaya \& Gamage, Sammani \& Ranaweera, Amaya \& Idroos, Ali. (2020). TOURISM AFTER CORONA: IMPACTS OF COVID 19 PANDEMIC AND WAY FORWARD FOR TOURISM, HOTEL AND MICE INDUSTRY IN SRI LANKA. 10.13140/RG.2.2.27955.17442.

[7] Kumar, Vineet. (2020). Indian Tourism Industry and COVID-19: Present Scenario. Journal of Tourism and Hospitality Education. 10. 179-185. 10.3126/jthe.v10i0.28768.

[8] Youssef, Adel \& Zeqiri, Adelina \& Dedaj, But. (2020). Short and Long Run Effects of COVID19 on the Hospitality Industry and the Potential Effects on Jet Fuel Markets.

[9] Dewan, Mayukh. (2020). Solutions for Surviving COVID-19: A Malaysian Hotel and Tourism Industry Perspective.

[10] Strielkowski, Wadim. (2020). International Tourism and COVID-19: Recovery Strategies for Tourism Organisations. 10.20944/preprints202003.0445.v1.

[11] Paul, Dhritabrata. (2020). Covid 19 Impact on Indian economy. 10.13140/RG.2.2.27275.23846.

[12] Sufi, Tahir. (2015). INDIAN HOTEL INDUSTRY: PAST, PRESENT AND FUTURE. 10.13140/RG.2.1.3065.1606.

[13] Sanjeev, Gunjan \& Bandyopadhyay, Rumki. (2016). Innovations in the Indian hospitality industry: an overview. Worldwide Hospitality and Tourism Themes. 8. 408-415. 10.1108/WHATT-05-2016-0026.

\section{BRIEF ABOUT AUTHOR:}

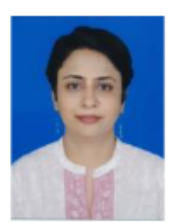

Dr Ruchita Verma, Dean - NMIMS School of Hospitality Management,NMIMS University

Dr. Ruchita Verma is a PHD (Management), MBA (Executive - General Management), MTM, PGD - Hotel Administration \& Management (IHM Mumbai - NCHMCT), Dip.HMCT (IHM Mumbai - NCHMCT). She is a results-oriented professional with a solid academic with 26 years of experience of working in hospitality \& design academics. As a lecturer, she began humbly and worked my way up to a director/dean position.Shewas born in South Mumbai, her schooling took place at the famous Jamnabai Narseee School (JNS). From JNS it was SNDT Juhu followed by Hotel Management at IHM Mumbai.

She currently serves as Dean of the Hospitality Management School NMIMS in Navi Mumbai. She was the campus director of Mumbai's Pearl Academy at her last assignment. She was Group Director for the ITM Institution Group before Pearl.

The Chairpersons of renowned universities in United States, United Kingdom, Australia, Canada and France have played a major role in the management of the end-to-end validation 
requirements by negotiation and facilitating collaborative relations with them. They also have played a major role. She has contributed detailed research papers, journals, conferences, seminars and workshops, tours of study and invitations to speak.

In 1991, she began her career as an MT for the Raheja Hotels Company. The Ambassador Hotels were accompanied by sales and marketing. In 1993, in Mumbai \& Navi Mumbai, several private catering colleges mushroomed and the faculty was in dearth. She heard about the opening at IHM and joined them as a professor in 1993 in Bharti Vidyapeeth. In 2002 she was hunted by a new university in her mind, after ten years in BVHMCT. She started working as a lecturer for ITM's IHM, then became a deputy head, headmaster and then group head of all their hospitality institutes throughout the world, and also their design institutes about 2 years before she left. In 2015 she wanted to challenge herself after finding herself happy in ITM. This led to an imaginative upsetting period of her life and she began her career in Mumbai as director of the Pearl Academy. Here, she had the chance to collaborate with designers and with talented people! NMIMS was just not able to resist when it offered her an opportunity to set up a hospitality school.

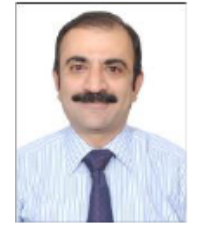

Dr.Ketan Chande,Associate Professor-F\&B Service,NMIMS, School of Hospitality Management,Kharghar, Navi Mumbai.

Dr. Ketan Chande is an experienced instructor with proven ability to educate, inspire and guide students while retaining high interest and achievement in hospitality operations. A communicator who can communicate efficiently with students at different academic levels. Keep good relationships with students, parents, faculty and administrators regularly. He has strong management and organising skills.

He has completed his Diploma in Hotel Management from the prestigious Institute of Hotel Management, Ahmedabad. After a good industry experience spanning to 15 years with hotels like The Leela, Mumbai and The Centaur, Mumbai and many other resorts, standalone restaurants and banquets, he ventured into the academics and further pursued his studies. $\mathrm{He}$ has completed his Masters in Tourism Management, MBA- General (elective Marketing), MBA- Education Management, Diploma in Training and Development from the Indian Society of Training and Development (ISTD), UGC-NET in Tourism Administration and PhD in Management.

He has worked with prestigious academic organizations in various capacities climbing the ladder from a Junior Lecturer to a Vice Principal. His major forte remains in imparting education in Hospitality institutes.

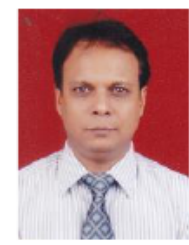

Mr.Bimal Kumar Ekka,Asst. Professor-F\&B Production,NMIMS, School of Hospitality Management,Kharghar, Navi Mumbai.

Bimal Kumar Ekka is an accommodation academic with more than 25 years of critical hospitality and tourism experience. Presently associated with Narse Monjee Institute of Management Studies, Global Campus, Navi Mumbai. Conduct courses for Hospitality subjects, Tourism and Marketing Management. Also impaneled as Trainer, Examiner and Verifier with TISS - School of Vocational Education for their Hospitality courses.

Completed Msc in Hotel Management and Catering Science. A graduate in hotel management from IHM, New Delhi who works in different parts of India and has also acquired excellent knowledge of the subject, varying curriculums and standards at various prestigious and renowned educational institutions. 
Headed Navi Mumbai campus of ITM institute of Hotel Management for 4 years and have been instrumental in starting 06 campuses / institutes. He has been the key responsible person in ITM, including the creation of companies, development of Tactical marketing initiatives; talent acquisition and retention; strategic partnership and networking; program/curriculum development; formation of organisational policies and processes.Prior to joining NMIMS, had been also associated with Pillai Institute of Management Studies as Asst. Professor conducting courses of Marketing and Service Management for two years.

An enthusiastic teacher who has been influential in the lives of young people and who has made a difference. As a communicator, it guides and offers students solutions through useful experience that create consensus easily. 